\title{
MATERNAL EMPLOYMENT STATUS, ETHNICITY, FOOD INTAKE, AND THEIR EFFECTS ON TEENAGE OBESITY, IN SURAKARTA
}

\author{
Rahmah Purwaningsih Febri Susanti ${ }^{1)}$, Bhisma Murti1), Dono Indarto ${ }^{2)}$ \\ ${ }^{1)}$ Masters Program in Public Health, Sebelas Maret University \\ 2)Faculty of Medicine, Sebelas Maret University
}

\begin{abstract}
Background: Obesity is one of the main causes of premature death in adulthood. The prevalence of teenage obesity in Indonesia has been increasing from $1.4 \%$ in 2007 to $7.3 \%$. It is hypothesized that the risk of obesity is influenced by lifestyle and socio-economic status. This study aimed to determine the effect of maternal job status, ethnicity, and food intake, on the risk of obesity in teenagers.

Subjects and Method: This was an analytical observational using casecontrol design. This study was conducted in Surakarta, in September November 2016. A total of 120 teenagers were selected for the study, consisting of 41 obese teenagers aged 16-18 years old and 79 normal weight teenagers, using fixed disease sampling. The dependent variable was obesity. The independent variables were maternal employment status, ethnicity, carbohydrate intake, fat intake, and energy intake. The data were collected using a set of questionnaires. Food intake was measured by 24 hour food recall. The data were analyzed using path analysis model.

Results: Energy intake had positive, significant, and direct effect on the risk of teenage obesity $(b=6.75 ; 95 \% \mathrm{CI}=4.36$ to $9.14 ; \mathrm{p}<0.001)$. Working mother indirectly had positive and significant effect on teenage obesity, via fat intake $(b=0.77 ; 95 \% \mathrm{CI}=0.03$ to $1.52 ; \mathrm{p}=0.040)$. Fat intake indirectly had positive and significant effect on teenage obesity, via energy intake $(b=4.16$; $95 \% \mathrm{CI}=1.95$ to $6.38 ; \mathrm{p}=0.001)$. Likewise, carbohydrateintake had positive and significant effect on teenage obesity, via energy intake $(b=3.31 ; 95 \% \mathrm{CI}=1.73$ to 4.88; $\mathrm{p}=0.001$ ). Ethnicity (Chinese versus Javanese) did not have significant effect on teenage obesity $(b=-1.14 ; 95 \% \mathrm{CI}=-3.56$ to $1.28 ; \mathrm{p}=0.355)$.

Conclusion: Energy intake has direct effect on the risk of teenage obesity. Fat intake, carbohydrate intake, and maternal employment status, have indirect effect on the risk of teenage obesity.
\end{abstract}

Keywords: maternal employment status, ethnicity, food intake, obesity, teenager.

Correspondence: Rahmah Purwaningsih Febri Susanti. Master Program in Public Health Sebelas Maret University. Email: rahmahpfs77@gmail.com 